\title{
Role of Optimism Bias and Risk Attitude on Investment Behaviour
}

\author{
Divya Gakhar \\ Guru Gobind Singh Indraprastha University, Delhi, India \\ Email: divya.ipu@gmail.com
}

How to cite this paper: Gakhar, D. (2019) Role of Optimism Bias and Risk Attitude on Investment Behaviour. Theoretical Economics Letters, 9, 852-871.

https://doi.org/10.4236/tel.2019.94056

Received: March 6, 2019

Accepted: April 12, 2019

Published: April 15, 2019

Copyright $\odot 2019$ by author(s) and Scientific Research Publishing Inc. This work is licensed under the Creative Commons Attribution International License (CC BY 4.0).

http://creativecommons.org/licenses/by/4.0/

\begin{abstract}
Purpose: The study undertakes to identify individual characteristics and their investment pattern. The individual characteristics include MBTI personality scores, risk taking behaviour, biases and investor demographics. Data and Methodology: A structured questionnaire was administered on 117 respondents in India. The questions were related to demographic variables, optimism bias, investment pattern and MBTI (Myers-Briggs Type Indicator ${ }^{\odot}$ ) personality assessment. The results were analysed using chi-square and ANOVA. Findings: The results show that presence of optimism bias in investors is influenced by marital status, nature of employment and work experience of investors. The Indian investors are majorly balanced or conservative out of the total sample in terms of risk taking behaviour. Risk taking attitude is affected by personality of individuals. Investment in high risk instruments is different among males and females, various age groups, marital status, and work place activity. Investment in medium risk instruments significantly differ for work experience on gender basis. Investment in low risk instruments does not differ for demographic variables of investors as all investors invest equally in safe investment mode. MBTI personality type is a less significant variable which directly affects investment patterns of Indian investors. The study can be useful for portfolio managers, investment advisors who can use it for designing investment portfolios and products for their clients based on their demographic, and behavioural profiling. Originality: This study identifies relationship between investment pattern, behavioural biases and demographic characteristics of Indian investors. MBTI personality assessment is one new dimension which is less researched in studying investment behaviour in Indian context.
\end{abstract}

\section{Keywords}

Investment Behavior, Investment Avenues, MBTI, Demographic Factors, Optimism Bias, Risk Taking Behavior 


\section{Introduction}

Standard finance theories of Capital Asset Pricing Model [1], Portfolio Theory given by Markowitz [2] and Efficient Market Hypothesis [3] assume investor to be rational and maximises expected utility. But behavioural researchers have found various evidences wherein investor decision making is not always rational and is affected by errors and biases. Investor behaviour and psychological biases that affect investment have now been researched by many. Prospect Theory propounded by Kahneman and Tversky [4] and Mental Accounting given by Thaler [5] are significant work in this regard. After the world has recovered from global financial crisis, behavioural finance has again gained importance in all countries of the world. Research studies have shown that investors are irrational and their investment decisions are affected by psychological biases, personality, demographics, experiences or heuristics [6] [7] [8].

Every investor has a different background, experience, work profile and investment needs and, therefore, make investment decision in various available avenues with a different mindset. Personality of an individual is also an important aspect which explains their behaviour. Investors base their investment decision based on objectives, risk taking capabilities, return expectation, and maintaining liquidity and profitability balance. Indian investor saving patterns usually include investments in low risk instruments like saving bank account, fixed deposits, provident funds, tax saving instruments, gold and government securities [9] and medium risk instruments like mutual funds, real estate and ETFs. The investors who are ready to take more risk, invest in capital markets in the form of equity, bonds and derivatives instruments [10].

The present study focuses on identifying the underlying factors that affect investment decision making by Indian investor. Some demographic variables like age, gender, work experience, understanding of finance, personality and marital status are important factors which can affect the type of investment alternatives an investor chooses. Risk taking ability and optimistic bias are other variables which can also affect investment choices. In this study, two behavioural biases have been studied on Indian investor, as Indians are known to be conservative investors and also optimism is an important trait of Indians. This study tries to open up new vistas of behavioural finance research in Indian context.

This paper is divided into following sub-sections: Section one introduces the study, next section reviews existing literature, third section explains the methodology, analysis and discussion is covered in section four, implications for practitioners is discussed in Section five and Section six concludes the paper.

\section{Review of Related Literature}

Empirical research proposes that investment behaviour is determined by factors such as wealth, education, cognitive abilities, social interaction, trust, as well as an individual's risk aversion. In this section studies on investment behaviour have been classified under demographic indicator, risk attitude, investment bi- 
ases, personality type and Indian scenario.

\subsection{Demographic Indicators and Investment Behaviour}

There has been less research done on demographic variables influence on investor behavior. Age and gender are the common variables shown to influence degree of risk aversion. It is found that women are more risk averse [11] [12] and less overconfident [13]. Younger investors are more aggressive as compared to older investors [14]. McLachan and Gardner [15] studied gender, age, and education level of Australian investors and investment in ethical funds. Age, income, and educational level were not found to be statistically significant. In a study of Austrian consumers, Getzner and Grabner-Krauter [16] found that higher education and higher income were the main explanatory variables for a consumer's willingness to choose green stocks for investments. It was also found that marital status plays an influencing role in profiling green consumers [17]. Hong, Kubik and Stein [18] show that social interaction is positively related to stock market participation as learning from friends and neighbours may reduce fixed participation costs. Marital status has also been found to affect asset allocation decisions [19]. Grinblatt, Keloharju, and Linnainmaa [20] found that IQ is positively related to stock market participation while IQ has long been recognized as having a significant genetic component. The younger investors have longer investment horizons, this result is consistent with the portfolio choice models of Lynch [21], Jurek and Viceira [22], and Larsen and Munk [23]. Men who are often more risk-seeking than women Croson and Gneezy [24] have an insignificant value tilt in their portfolios. Besides age, only disposable income has a significant effect on the portfolio's value/growth orientation.

Barnea et al. [6] found that a genetic factor explains about one third of the variance in stock market participation and asset allocation. Family environment has an effect on the behavior of young individuals, but this effect is not longlasting and disappears as an individual gains experiences. Malmendier and Nagel [25] in their "Depression Babies" show that individuals who have experienced relatively low stock market returns in their lives subsequently do not participate in the stock market and they take significantly less financial risk if they do participate.

\subsection{Risk Attitude and Investment Behaviour}

It was also seen that Managers will be less willing to take risk as their age increases [26]. Literature on labour economics and management emphasizes that with age risk-aversion increases [27] [28] [29] [30]. Studies in sociology literature also supports this idea [31] [32]. Older managers will have more confidence in their abilities so they do more aggressive trading as compared to young managers [33]. Graham [26], Li [34], Boyson [35] analysed that risk taking in financial sector decreases with age and experience of managers. The results observed negative relation between risk taking and experience. But, Chevalier and Ellison [36]; Hong et al. [37]; and Lamont [38] come to opposite conclusions. Studies 
have also reported that young and inexperienced fund managers earn higher returns as compared to more experienced colleagues [39], Liang [40] and Edwards and Caglayan [41].

It was also found that female managers have higher degree of loss aversion and risk aversion as compared to men [42] and Schmidt and Traub [43]. Individual biological differences also have an impact on risk taking attitude [44] [45]. A common bias is that men are more attracted to risk than women are. The difference is biological as well as also caused by socio-cultural factors. The society as a whole has always set boundaries for both genders which creates a structural mindset in peoples' brain. It has been found that older individual and women are more risk averse compared to younger individuals and men [24]. Charness and Gneezy [46] found that women traded less than men did. Byrnes et al. [47] compared male and female risk taking and discovered that the percentage of women agreeing any risk is less than the percentage of men offered the same risky choice.

Olsen [48] tries to investigate the implications of human consciousness relative to financial risk perceptions through a survey called Qualia. It was concluded that financial risk perceptions are Qualia and as such should have a strong affective influence on risk perceptions. It was concluded by Trimpop (1994), risk takers are generally better educated, they have a record of lucrative risk taking, allow ambiguity, hunt for innovative experiences and can quickly react to stimuli. They are considered as flexible, audacious, aggressive, relaxed, confident and outgoing. Risk takers are typical Type-A personalities. Higher is the income and education risk propensity also increases [49].

Merikas et al. [50] analyzed factors influencing Greek investor behaviour on the Athens Stock Exchange (ASE). The authors found that investors base their stock purchase decisions on economic criteria combined with other diverse variables. Kim and Nofsinger [51] studied investors in the Japanese markets and examined their behaviour and performance. The results show that Japanese investors own risky and high book-to-market stocks, trade frequently and make poor trading decisions. The poor performance by investors can largely be explained by tendency to hold value stocks during bull phase and high risk stocks during bear phase.

\subsection{Investment Biases and Investor Behaviour}

Lasfer et al. [52] found that foreign investors have optimistic bias in terms of tock investments as compared to domestic investors. Nofsinger [51] defined optimistic investor as he tend to do less critical analysis in making stock decision and optimists like to ignore negative information about their stocks.

Lim [53] analysed that trading decisions of investors are influenced by their preferences for framing of gains and losses. Thaler [5] suggest that mental accounting play a significant role in investor behaviour. Brown and Cliff [54] investigated investor sentiment and its relation to near-term stock market returns. The results show that sentiment has little predictive power for near-term future 
stock returns. Fischer and Gerhardt [55] studied individual investor investment decision making and found that individual investor investment decisions deviate from financial theory. Financial advice is correcting factor in investment decision making process.

Studies related to overconfidence bias has [56] shown that investors who are overconfident choose more risky portfolios. Young and inexperienced fund managers were found to be more overconfident and earn higher returns. Gakhar and Prakash [57] found that overconfidence bias as investor's attitude is not affected by gender, age, work experience, workplace activity, MBTI personality type and marital status of investors. There is some empirical evidence that suggest that overconfidence of investors decrease with experience [58]. However, other studies have shown that experts are overconfident than inexperienced managers [59] [60]. Professionals are significantly more overconfident than laymen as reported in Glaser et al. [61].

\subsection{Personality Type and Investment Behaviour}

Filbeck, Hatfield and Horvath [62] studied personality types and investment decisions. They administered the Myers-Briggs Type Indicator to a group of college students and also administered a survey of risk tolerance. The Myers-Briggs is divided into four dichotomies: Extraversion-Introversion, Sensing-Intuitive, Thinking-Feeling and Judging-Perceiving. In their results, the thinking dimension of the MBTI had a preference for more risk-taking in the form of both variance and skewness. Those with the judging dimension also indicated a strong preference for variance. Durand et al. [63] [64] measured the personality using the short form of the NEO-PIR instrument, the NEO-FFI developed by Costa and McRae [65] which is based on Norman's (1963) "Big Five" personality constructs of negative emotion, extraversion, openness to experience, agreeableness and conscientiousness. The paper measures psychological gender using questions developed by Bem [66]. Preference for innovation and risk-taking propensity are measured using instruments developed by Jackson [67]. The paper then examines the behavior of the subject who traded interactively in "real time" in an interactive-simulated foreign exchange market where "price discovery" was instantaneous and pricing decisions were made instantaneously as items of news, determined by the researchers, were released. The paper concluded that personality traits are associated with overconfidence and overreaction in financial markets.

\subsection{Investment Behaviour in Indian Scenario}

Chakarborty and Digal [10] attempts to analyse the investment pattern, saving objective and preferences of individual investor's for various investment options available in India. The result shows that, objective to saving is significantly influenced by demographic factors such as age, occupation and the income level of investors. 
Shollapurand Kuchanur [68] concluded that corporate securities are less preferred, government securities do not provide regular and steady income, investment in insurance policies appreciate in values and bank deposits require more transaction costs. Sellappan [69] found that married women are more curious in making investment than the unmarried. Younger generation is mostly like to invest in shares, mutual funds, insurance and fixed deposits than the older women. Pati and Shome [70] revealed that households are still preferring the safe channel of bank deposit schemes rather than switching over to high yielding but risky channels of savings.

Mohanta and Debasish [71] concluded that income and occupation of investor affect the investment avenue chosen by male and female investors. Chaturvedi and Khare [72] revealed that there is impact of age, education, occupation and income of the individual on his investments.

The review of related studies concludes that there has been less work on this subject done in Indian context. Also many studies have considered demographic variables, but they have not tried to relate it with investment pattern of investors. There are few studies based on optimism bias but in Indian scenario carries optimistic attitude as a part of their culture so, it can be studied. Indian people are generally conservative so India could survive through the global financial crisis in shorter time. Finally, very few studies have talked about personality and investment behaviour in Indian context so, it has been taken up in this study.

\section{Methodology}

The present study attempts to study the factors which affect the investment behaviour of Indian investor. Risk taking attitude, optimism bias and personality of investor is also affecting their investment pattern. The objective of the study is to understand the relationship between individual investor characteristics and their investment pattern. The individual characteristics include demographic variables, MBTI personality scores, risk taking attitude and optimism bias.

For collecting the data, 300 questionnaires were distributed out of which 189 questionnaires were received back, out of which 77 questionnaires were rejected as they were incomplete. So, the study has been carried out on 117 respondents in India. The structured questionnaire consisted of questions relating to demographic variables, optimism bias, risk taking behaviour, investment pattern and MBTI (Myers-Briggs Type Indicator ${ }^{\circledR}$ ) personality assessment. The questionnaire has been developed by adapting some questions on risk taking ability from investor profile questionnaire developed by BMO Insurance [73] and on optimism bias from Pompian [74]. Optimism bias was analysed using diagnostic testing defined by Pompian [74] which detects signs of cognitive bias stemming from excess optimism. It consisted of four questions and scores of investors were categorised as optimistic and pessimistic investors. For the various categories of investment avenues, data was collected from investor in terms of where they will put their money if Rs.100,000 is given to them for investment. MBTI personality 
scale was used as it covers various aspects of personality in detail. After compiling questions expert validation of questionnaire was carried out. Cronbach alpha reliability was measured and a highly significant score of 0.702 was found.

The MBTI assessment test is a popular personality assessment model which describes 16 personality types based on four categories. These are:

1) Based on individuals' interaction with the world and his energy towards it, individuals are classified as Extroverts and Introverts-E or I.

2) Based on what kind of information a person receives, personality can be classified asSensing or Intuitive-S or $\mathrm{N}$.

3) Based on process of making decisions classification is Thinking or Feeling type-T or F.

4) Based on how someone prefers to live, in a structured or a spontaneous way, he/she is classified as Judging or Perceiving-J or P.

Everyone is a combination of four letters taking one letter from each category. Thus, the sixteen personality types are ISTJ, INFJ, ISTP, ISFJ, INTJ, ISFP, INTP, INFP, ESTP, ENFP, ENTP, ESTJ, ESFJ, ESFP, ENFJ, and ENTJ.

The results were analysed using descriptive statistics, chi-square test, ANOVA, post hoc test and independent sample t-test using SPSS 22.

The following hypotheses of the study were framed:

\section{Hypotheses}

$H_{01}$ : There is no significant relationship between demographic variables and optimism bias.

$H_{02}$ : There is no significant relationship between risk taking behaviour of males and females.

$H_{03}$ : There is no significant relationship between risk taking behaviour and MBTI Personality type of investors.

$H_{04}$ : There is no significant relationship between demographic variables and high risk investment instruments.

$H_{05}$ : There is no significant relationship between demographic variables and medium risk investment instruments.

$H_{06}$ : There is no significant relationship between demographic variables and low risk investment instruments.

$H_{07}$ : There is no significant relationship between investment pattern and MBTI Personality type of investors.

\section{Analysis and Discussions}

The data was collected from 117 respondents taken for the study. Table 1, shows the classification of sample respondents.

Out of 117 respondents 77.80 percent were males. There were 83.80 percent respondents in the age group of 20 - 35 years in the sample. Unmarried respondents were 65.80 percent and sample distribution shows 56.20 percent were from corporate sector. Out of the total sample, 68.10 percent respondents have less than 5 years of work experience. 
Table 1. Sample profile of respondents.

\begin{tabular}{|c|c|c|c|}
\hline & & Frequency & Percent \\
\hline \multirow{2}{*}{ Gender } & Male & 91 & 77.80 \\
\hline & Female & 26 & 22.20 \\
\hline \multirow{3}{*}{ Age } & 20 - 35 years & 98 & 83.80 \\
\hline & $35-50$ years & 17 & 14.50 \\
\hline & $50-65$ years & 2 & 1.70 \\
\hline \multirow{2}{*}{ Marital Status } & Married & 40 & 34.20 \\
\hline & Unmarried & 77 & 65.80 \\
\hline \multirow{5}{*}{ Nature of Employment } & Self Employed & 11 & 9.80 \\
\hline & Government Employee & 25 & 22.30 \\
\hline & Corporate Sector & 63 & 56.20 \\
\hline & Non-Corporate Sector & 8 & 7.10 \\
\hline & Not Employed & 4 & 3.60 \\
\hline \multirow{2}{*}{ Workplace Activity } & Finance Related & 18 & 17.50 \\
\hline & Non-Finance Related & 85 & 82.50 \\
\hline \multirow{4}{*}{ Work Experience } & $1-5$ years & 79 & 68.10 \\
\hline & $5-10$ years & 19 & 16.40 \\
\hline & $10-15$ years & 6 & 5.20 \\
\hline & 15 years and above & 12 & 10.30 \\
\hline
\end{tabular}

Authors Calculations.

Table 2 shows gender wise distribution of MBTI personality types of investors. It is clear from the table that 20.90 percent respondents are ESTJ, 19.80 percent are ISTJ, 12.10 percent are ENTJ and 8.80 percent males are INFJ. Out of the sample 19.20 percent females are INFJ, 11.50 percent are ENTJ, ESTJ, INTJ, ISFJ and ISTJ.

Table 3 shows investment in various instruments by Indian investors. 60.09 percent of average total investment is done in less risky investment instruments like Saving Bank account, Fixed Deposit account, Provident Fund and Government Securities etc. with standard deviation of 36.156 [9]. Further, investment in medium risk investment instruments which includes Gold, Mutual funds and Real estate is 18.66 percent. Only 2.94 percent of total funds are invested in high risky instruments of investment like bonds, equity and derivatives Chakraborty et al. [10].

Further analysis was carried out to identify optimism bias among investors which has been discussed in Table 4. Optimism bias causes investors to feel that nothing negative will happen to them as compared to others [74]. Balasuriya et al. [75] defined optimism as overestimation of favourable result in future.

Majority of males (71.40 percent) are optimist and 57.70 percent of females are optimist. The chi-square result of 1.765 is insignificant (0.184) which reflects 
Table 2. Gender vs. MBTI personality types.

\begin{tabular}{|c|c|c|c|c|}
\hline \multirow{2}{*}{ MBTI Personality Types } & \multicolumn{2}{|c|}{ Male } & \multicolumn{2}{|c|}{ Female } \\
\hline & Frequency & Percent & Frequency & Percent \\
\hline ENFJ & 4 & 4.40 & 1 & 3.80 \\
\hline ENFP & 3 & 3.30 & 0 & 0.00 \\
\hline ENTJ & 11 & 12.10 & 3 & 11.50 \\
\hline ENTP & 3 & 3.30 & 1 & 3.80 \\
\hline ESFJ & 4 & 4.40 & 1 & 3.80 \\
\hline ESFP & 3 & 3.30 & 2 & 7.70 \\
\hline ESTJ & 19 & 20.90 & 3 & 11.50 \\
\hline ESTP & 4 & 4.40 & 1 & 3.80 \\
\hline INFJ & 8 & 8.80 & 5 & 19.20 \\
\hline INTJ & 8 & 8.80 & 3 & 11.50 \\
\hline INTP & 1 & 1.10 & 0 & 0.00 \\
\hline ISFJ & 1 & 1.10 & 3 & 11.50 \\
\hline ISFP & 3 & 3.30 & 0 & 0.00 \\
\hline ISTJ & 18 & 19.80 & 3 & 11.50 \\
\hline ISTP & 1 & 1.10 & 0 & 0.00 \\
\hline INFP & 0 & 0.00 & 0 & 0.00 \\
\hline Total & 91 & 100.00 & 26 & 100.00 \\
\hline
\end{tabular}

Authors Calculations.

Table 3. Descriptive statistics of investment in various instruments.

\begin{tabular}{ccccccccc}
\hline & Mean & Median & Std. Deviation & Skewness & Kurtosis & Range & Minimum & Maximum \\
\hline $\begin{array}{c}\text { Low Risk Investment } \\
\text { Instruments }\end{array}$ & 60.09 & 60 & 36.156 & -0.419 & -1.169 & 100 & 0 & 100 \\
$\begin{array}{c}\text { Medium Risk Investment } \\
\text { Instruments }\end{array}$ & 18.66 & 5 & 25.272 & 1.421 & 1.305 & 100 & 0 & 100 \\
$\begin{array}{c}\text { High Risk Market } \\
\text { Instruments }\end{array}$ & 2.94 & 0 & 6.755 & 2.39 & 4.906 & 30 & 0 & 30 \\
\hline
\end{tabular}

Authors Calculations.

that null hypothesis could not be rejected. Males and females were not found to be different in terms of optimism.

Respondents in 20 - 35 age group are optimist (65.30 percent) and 82.40 percent respondents between the age group of 35 - 50 years are optimist. The chi-square result is not significant (0.236). The result of chi square test (10.280) between optimism bias and marital status of respondent is found to be significant ( 0.001 level of significance). 87.50 percent of married investors are found to be optimist as compared with 41.60 percent of unmarried investors. 80 percent of government employees and 87.50 percent of employees are in non-corporate 
Table 4. Demographic factors and optimism bias among investors.

\begin{tabular}{|c|c|c|c|c|c|}
\hline & & Pessimist & Optimist & Total & $\begin{array}{c}\text { Chi } \\
\text { Square Result }\end{array}$ \\
\hline \multirow{3}{*}{ Gender } & Male & 28.60 & 71.40 & 100.00 & \multirow{3}{*}{$1.765(0.184)$} \\
\hline & Female & 42.30 & 57.70 & 100.00 & \\
\hline & Total & 31.60 & 68.40 & 100.00 & \\
\hline \multirow{4}{*}{ Age } & $20-35$ years & 34.70 & 65.30 & 100.00 & \multirow{4}{*}{$2.888(0.236)$} \\
\hline & 35 - 50 years & 17.60 & 82.40 & 100.00 & \\
\hline & $50-65$ years & 0.00 & 100.00 & 100.00 & \\
\hline & Total & 31.60 & 68.40 & 100.00 & \\
\hline \multirow{3}{*}{$\begin{array}{l}\text { Marital } \\
\text { Status }\end{array}$} & Married & 12.50 & 87.50 & 100.00 & \multirow{3}{*}{$10.280(0.001)^{\star}$} \\
\hline & Unmarried & 41.60 & 58.40 & 100.00 & \\
\hline & Total & 31.60 & 68.40 & 100.00 & \\
\hline \multirow{6}{*}{$\begin{array}{c}\text { Nature of } \\
\text { Employment }\end{array}$} & Self Employed & 45.50 & 54.50 & 100.00 & \multirow{6}{*}{$12.457(0.014)^{\star}$} \\
\hline & Government Employee & 20.00 & 80.00 & 100.00 & \\
\hline & Corporate Sector & 32.80 & 67.20 & 100.00 & \\
\hline & Non-Corporate Sector & 12.50 & 87.50 & 100.00 & \\
\hline & Not Employed & 100.00 & 0.00 & 100.00 & \\
\hline & Total & 32.10 & 67.90 & 100.00 & \\
\hline \multirow{3}{*}{$\begin{array}{l}\text { Workplace } \\
\text { Activity }\end{array}$} & Finance Related & 27.80 & 72.20 & 100.00 & \multirow{3}{*}{$0.091(0.762)$} \\
\hline & Non-Finance Related & 31.40 & 68.60 & 100.00 & \\
\hline & Total & 30.80 & 69.20 & 100.00 & \\
\hline \multirow{5}{*}{$\begin{array}{c}\text { Work } \\
\text { Experience }\end{array}$} & $1-5$ years & 38.00 & 62.00 & 100.00 & \multirow{5}{*}{$6.130(0.015)^{*}$} \\
\hline & $5-10$ years & 21.10 & 78.90 & 100.00 & \\
\hline & $10-15$ years & 16.70 & 83.30 & 100.00 & \\
\hline & 15 years and above & 8.30 & 91.70 & 100.00 & \\
\hline & Total & 31.00 & 69.00 & 100.00 & \\
\hline
\end{tabular}

*highly significant at 0.05 percent level of significance. Authors Calculations.

sector are optimist. 45.50 percent of self-employed are pessimist in nature. The chi square results of 12.45 percent show significant values. Workplace activity and optimism bias are not significantly related so, null hypothesis is accepted. The chi square result of 6.130 between respondents having work experience and level of optimism is found to be significant.

It can be concluded that level of optimism of investors is affected by marital status, nature of employment and work experience of investors. Age, gender and work place activity doesn't affect optimistic or pessimistic behaviour of investors. Null hypothesis $\left(H_{01}\right)$ is rejected for marital status, nature of employment and work experience of investors with respect to optimism bias.

Table 5 depicts relationship between risk taking behaviour of respondents and gender. Overall 37.90 percent of Indian investors are conservative and only 
Table 5. Gender and risk taking behaviour among investors.

\begin{tabular}{cccccc}
\hline & $\begin{array}{c}\text { Conservative } \\
\text { Investor }\end{array}$ & $\begin{array}{c}\text { Balanced } \\
\text { Investor }\end{array}$ & $\begin{array}{c}\text { Aggressive } \\
\text { Investor }\end{array}$ & Total & $\begin{array}{c}\text { Chi-Square } \\
\text { Test }\end{array}$ \\
\hline Males & 38.50 & 59.30 & 2.20 & 100.00 & \\
Females & 36.00 & 64.00 & 0.00 & 100.00 & $0.651(0.772)$ \\
Total & 37.90 & 60.30 & 1.70 & 100.00 & \\
\hline
\end{tabular}

Authors Calculations.

1.70 percent investors are aggressive in nature. Based on gender it was found that 59.30 percent males and 64 percent females are balanced investors. The chi square result 0.651 is insignificant and null hypothesis $\left(H_{02}\right)$ is accepted.

Table 6 explains risk taking behaviour of Indian investors in relation to their MBTI personality type. The chi square result is 89.053 , which is highly significant $(0.000)$, shows that risk taking behaviour of investors differ with their personalities.

71.40 percent investors who are having ESTJ personality are balanced. 76.90 percent INFJ and 71.40 percent ISTJ are balanced investors. 100 percent ISFP, 100 percent INTP and 100 percent ISTP are aggressive investors. Thus, null hypothesis $\left(H_{03}\right)$ is rejected.

Table 7 depicts relationship between investment pattern and demographic variables of investors. The total investment made by investors classified into high risk investment instrument (equity and derivatives etc.) medium risk investment instrument (mutual fund, ETFs, real estate etc.) and low risk or risk free investment instrument (saving account, fixed deposites etc.)

The results of ANOVA on high risk instrument and gender is found to be significant with $F$ value of 6.642 and (0.011) level of significance, so high risk investment pattern significantly differ for males and females. These finding are similar to those of Lascu [11] and Loible and Hira [12]. Independent sample t-test shows males invest more in high risk instruments as compared to females ( $\mathrm{t}$ value $=2.577$ and $\mathrm{p}$ value $=0.011)$. The ANOVA result $(\mathrm{F}-7.356)$ is significant (0.008) for medium risk investment instrument and gender. Males and females significantly differ in medium risk investment. Levene's t-test shows that males invest more than females $(\mathrm{t}$ value $=2.712$, $\mathrm{p}$ value $=0.008)$ in medium risk intruments. The investment pattern of low risk instrument by males and females doesn't have significant difference. Total investment by males and females is significantly different for both the groups as shown by $\mathrm{F}$ value 7.684 with (0.007) level of significance. Further independent sample t-test show that a $t$-value of -2.328 (0.021 level of significance which shows that females invest more than males in total investment.

Results of ANOVA (13.171) between high risk investment pattern of investors of various age groups is significantly different at (0.000) level of significance. It shows that investment in risky instrument is different for people of different age groups. As more the age, lower is the risk taking capacity of the investors [75]. 
Table 6. MBTI personality types and risk taking behaviour.

\begin{tabular}{ccccc}
\hline $\begin{array}{c}\text { MBTI } \\
\text { Personality Types }\end{array}$ & $\begin{array}{c}\text { Conservative } \\
\text { Investor (percent) }\end{array}$ & $\begin{array}{c}\text { Balanced } \\
\text { Investor (percent) }\end{array}$ & $\begin{array}{c}\text { Aggressive } \\
\text { Investor (percent) }\end{array}$ & Total \\
\hline ENFJ & 100.00 & 0.00 & 0.00 & 100.00 \\
ENFP & 100.00 & 0.00 & 0.00 & 100.00 \\
ENTJ & 35.70 & 64.30 & 0.00 & 100.00 \\
ENTP & 25.00 & 75.00 & 0.00 & 100.00 \\
ESFJ & 0.00 & 100.00 & 0.00 & 100.00 \\
ESFP & 40.00 & 60.00 & 0.00 & 100.00 \\
ESTJ & 28.60 & 71.40 & 0.00 & 100.00 \\
ESTP & 40.00 & 60.00 & 0.00 & 100.00 \\
INFJ & 23.10 & 76.90 & 0.00 & 100.00 \\
INTJ & 45.50 & 54.50 & 0.00 & 100.00 \\
INTP & 100.00 & 0.00 & 0.00 & 100.00 \\
ISFJ & 75.00 & 25.00 & 0.00 & 100.00 \\
ISFP & 100.00 & 0.00 & 0.00 & 100.00 \\
ISTJ & 23.80 & 71.40 & 4.80 & 100.00 \\
ISTP & 0.00 & 0.00 & 100.00 & 100.00 \\
Total & 37.90 & 60.30 & 1.70 & 100.00 \\
Chi-square Test & 89.053 & Sign & $0.000^{*}$ & \\
\hline
\end{tabular}

*highly significant at 0.05 percent level of significance. Authors Calculations.

Table 7. ANOVA results on investment pattern and demographic variables.

\begin{tabular}{cccccccccc}
\hline & $\begin{array}{c}\text { High Risk } \\
\text { Market }\end{array}$ & $\begin{array}{c}\text { Medium Risk } \\
\text { Investment } \\
\text { Demographic Variables }\end{array}$ & $\begin{array}{c}\text { Low Risk } \\
\text { Instruments }\end{array}$ & $\begin{array}{c}\text { Instruments } \\
\text { Investment } \\
\text { Instruments }\end{array}$ & $\begin{array}{c}\text { Total } \\
\text { Investments }\end{array}$ \\
\cline { 2 - 9 } & F value & Sign. & F value & Sign. & F Value & Sign. & F value & Sign. \\
\hline Gender & 6.642 & $0.011^{*}$ & 7.356 & $0.008^{*}$ & 0.125 & 0.724 & 7.684 & $0.007^{*}$ \\
Age & 13.171 & $0^{*}$ & 0.388 & 0.679 & 0.326 & 0.722 & 2.888 & 0.236 \\
Marital Status & 6.509 & $0.012^{*}$ & 5.629 & 0.019 & 0.44 & 0.508 & 2.959 & $0.088^{*}$ \\
Workplace Activity & 6.553 & $0^{*}$ & 1.085 & 0.368 & 0.896 & 0.469 & 2.1 & 0.356 \\
Work Experience & 0.069 & 0.794 & 6.598 & $0.012^{*}$ & 0.157 & 0.693 & 2.356 & 0.651 \\
Optimism Bias & 1.307 & 0.255 & 6.02 & $0.016^{*}$ & 0.056 & 0.814 & 0.032 & 0.858 \\
Risk Taking Behaviour & 0.205 & 0.815 & 10.088 & $0.000^{*}$ & 1.964 & 0.145 & 0.877 & 0.418 \\
MBTI Personality Type & 0.462 & 0.948 & 1.501 & 0.124 & 1.269 & 0.239 & 0.726 & 0.744 \\
\hline
\end{tabular}

Source: Calculated values from data. ${ }^{\star}$ Highly significant at 0.05 percent level. Authors Calculations.

The results of levene's t-test show that investor in age group of 20 - 35 years invest more in high risk intruments as compared to age group of 35 - 50 years $(\mathrm{t}$ value $=2.409$, $\mathrm{p}$ value $=0.018)$

The ANOVA results (6.509) on high risk investment is significant (0.012) for married and unmarried investors. This shows that risky investment decision of both married and unmarried investor is different. Independent sample t-test re- 
sults show married investor invest more in high risk intruments as compared to unmarried investor ( $\mathrm{t}$ value $=2.551, \mathrm{p}$ value $=0.012$ ). Medium risk investments (F value 5.629) is highly significant at (0.019) with respect to marital status of investors. Under medium risk instruments category, it is seen that married investors have more investment as compared to unmarried investor $(t=2.373, p$ value $=0.019)$. The null hypothesis is therefore rejected total investment is made by married and unmarried investors significantly differ at 0.088 level of significance. Thus null hypothesis is rejected.

High risk investment significantly differ (at 0.000 level of significance) for finance related work profile and non finance related work profiles. The null hypothesis is rejected and this shows that finance professionals invest more in risky instruments as compared to non-finance professionals $(\mathrm{t}$ value $=2.569, \mathrm{p}$ value $=$ 0.012).

ANOVA results for medium risk investment with respect to work experience are found to be highly significant ( 0.012 level of significant). This shows that investors with different level of work experience respond differently when it comes to investment in mutual funds and real estate etc. There is significant difference in the investments of investors with 1 - 5 years of work experience and those who have more than 15 years of experience (post hoc ANOVA result $\mathrm{F}=8.824$, $\mathrm{p}$ value $=0.000$ )

Optimism bias is found to be highly significant in determining investment in medium risk instruments $(\mathrm{F}$ value $=6.02, \mathrm{p}$ Value $=0.016)$. Further analysis shows that optimist tend to invest more in medium risk instruments as compared to pessimists $(\mathrm{t}$ value $=-2.454, \mathrm{p}$ value $=0.016)$.

Risk taking behaviour is found to be significantly different for medium risk investment instrument category with $\mathrm{F}$ value of 10.088 (0.000 signifiance level). Table 8 shows results of Scheffe's post hoc test, which depict that there is significant difference between investment in medium risk instrument of aggressive investor and conservative investor (72.955) at 0.000 level of significance and also between aggressive investor and balanced investor (0.001 level of significance).

ANOVA ( $F$ value 0.462$)$ result is insignificant ( 0.948 level) which accepts the null hypothesis that MBTI personality types don't affect investment pattern in high risk instrument. Low risk investments ( $F$ value 1.269) is also insignificant (0.239) with respect to personality of investors. For medium risk instruments personality is significant at 12 percent level of significance with $\mathrm{F}$ value of 1.501 . So, null hypothesis is accepted that there is no significant difference in investment behaviour of investors with different personality types.

The study comes out with some interesting results. Table 6 concludes that risk taking behaviour significantly differs for individuals having different personality types. Table 7 shows that risk taking behaviour significantly differs for medium risk investment instruments. Risk taking behaviour is a significant variable and there is difference in the medium risk investment by aggressive investor, balanced investor and conservative investor (Table 8). Results in Table 7 also proves that personality type of investor is a significant factor for medium risk 
investments, but its level of significance is low (12 percent level of significance). This also concludes that personality of individual determines his risk taking behaviour which will determine investment instruments chosen by him.

To conclude we can say that total investment by investors significantly differ with respect to gender and marital status of investors. Investment in high risk instruments is different for males and females, various age groups, marital status, and work place activity. So, null hypothesis $\left(\mathrm{H}_{04}\right)$ is rejected (Table 9). Investment in medium risk instrument significantly differ for work experience,

Table 8. Scheffe post Hoc test for medium risk investment instruments and risk taking behaviour.

\begin{tabular}{|c|c|c|c|c|c|c|}
\hline \multirow{2}{*}{$\begin{array}{c}\text { (I) Risk } \\
\text { Taking } \\
\text { Behaviour }\end{array}$} & \multirow{2}{*}{$\begin{array}{l}\text { (J) Risk Taking } \\
\text { Behaviour }\end{array}$} & \multirow{2}{*}{$\begin{array}{c}\text { Mean } \\
\text { Difference } \\
(\mathrm{I}-\mathrm{J})\end{array}$} & \multirow{2}{*}{$\begin{array}{l}\text { Std. } \\
\text { Error }\end{array}$} & \multirow[b]{2}{*}{ Sig. } & \multicolumn{2}{|c|}{$95 \%$ Confidence Interval } \\
\hline & & & & & $\begin{array}{l}\text { Lower } \\
\text { Bound }\end{array}$ & $\begin{array}{l}\text { Upper } \\
\text { Bound }\end{array}$ \\
\hline Conservative & Balanced Investor & -9.14 & 4.527 & 0.135 & -20.37 & 2.09 \\
\hline Investor & Aggressive Investor & $-72.955^{\star}$ & 17.012 & 0.000 & -115.15 & -30.76 \\
\hline Balanced & Conservative Investor & 9.14 & 4.527 & 0.135 & -2.09 & 20.37 \\
\hline Investor & Aggressive Investor & $-63.814^{\star}$ & 16.874 & 0.001 & -105.67 & -21.96 \\
\hline Aggressive & Conservative Investor & $72.955^{\star}$ & 17.012 & 0.000 & 30.76 & 115.15 \\
\hline Investor & Balanced Investor & $63.814^{*}$ & 16.874 & 0.001 & 21.96 & 105.67 \\
\hline
\end{tabular}

*highly significant at 0.05 percent level of significance. Authors Calculations.

Table 9. Summary of hypotheses testing results.

\begin{tabular}{|c|c|c|}
\hline Null Hypotheses & $\begin{array}{l}\text { Accepted } \\
\text { or Rejected }\end{array}$ & $\begin{array}{l}\text { Variables } \\
\text { Significant }\end{array}$ \\
\hline $\begin{array}{l}H_{01} \text { : There is no significant relationship between } \\
\text { demographic variables and optimism bias. }\end{array}$ & Rejected & $\begin{array}{l}\text { marital status, } \\
\text { nature of } \\
\text { employment, } \\
\text { work experience }\end{array}$ \\
\hline $\begin{array}{l}H_{02} \text { : There is no significant relationship between } \\
\text { risk taking behaviour of males and females. }\end{array}$ & Accepted & \\
\hline $\begin{array}{l}H_{03} \text { : There is no significant relationship between risk taking } \\
\text { behaviour and MBTI Personality type of investors. }\end{array}$ & Rejected & Personality Type \\
\hline $\begin{array}{l}H_{04} \text { : There is no significant relationship between demographic } \\
\text { variables and high risk investment instruments. }\end{array}$ & Rejected & $\begin{array}{l}\text { Gender, age, } \\
\text { marital status, } \\
\text { work place activity }\end{array}$ \\
\hline $\begin{array}{l}H_{05} \text { : There is no significant relationship between demographic } \\
\text { variables and medium risk investment instruments. }\end{array}$ & Rejected & $\begin{array}{l}\text { work experience, } \\
\text { gender, risk } \\
\text { taking attitude }\end{array}$ \\
\hline $\begin{array}{l}H_{06} \text { : There is no significant relationship between demographic } \\
\text { variables and low risk investment instruments. }\end{array}$ & Accepted & \\
\hline $\begin{array}{l}H_{07} \text { : There is no significant relationship between investment } \\
\text { pattern and MBTI Personality type of investors. }\end{array}$ & Accepted & $\begin{array}{l}\text { Personality has } \\
\text { impact on medium } \\
\text { risk investments }\end{array}$ \\
\hline
\end{tabular}

Authors Calculations. 
gender of investors and risk taking attitude. So, null hypothesis $\left(\mathrm{H}_{05}\right)$ is rejected.

Investment in low risk instruments does not differ for demographic variables of investors as all investors invest equally in safe investment mode. Thus null hypothesis $H_{06}$ is accepted. MBTI personality type is not an important determinant for investment pettern of Indian investors (null hypothesis $H_{07}$ is accepted).

\section{Implications of the Study}

The results of this study can be highly useful for investment advisors, portfolio managers, financial investment agencies as they can choose and define a product for their clients based on their gender, age, work experience, marital status, personality type and risk taking attitude. The investment advisors should try to evaluate personality of their client before offering them any product. This can be done by using various psychographic personality tests which are available. While designing a portfolio for investment risk return behaviour is very important and personality is found to be highly significant with respect to risk taking behaviour. So, understanding personality of investors is very crucial. Then they should try to map other demographic variables of their client like age, gender, risk taking ability, investment biases, work experience and workplace activity with their personalities. Thereafter they can design an investment programme wherein a combination of low risk, medium risk and high risk investment instruments is made.

\section{Conclusions}

This study tries to establish relationship between investment behaviour of Indian investors and demographic variables, optimism bias, risk taking behaviour and MBTI personality types. Out of sample 77.80 percent were males. 83.80 percent were respondents were between the age group of 20 - 35 years. 20.90 percent males were of ESTJ personality, 19.80 percent were of ISTJ personality and 12.10 percent were of ENTJ personality. Out of the sample 19.20 percent females were INFJ personalities. The results establish that 68.40 percent Indian investors are optimist. Optimism bias in investors is affected by marital status, nature of employment and work experience of investors. It was found that most of Indian investors are balanced or conservative in terms of their investment behaviour. MBTI is a significant factor which affects risk taking behaviour of investors. Gender is nonsignificant with respect to investor's risk taking behaviour. Total investment by Indian investors significantly differs with respect to gender and marital status of investors. Investment in high risk instruments is different for males and females, various age groups, marital status, and work place activity. Investment in medium risk instrument significantly differs for work experience, risk taking attitude, optimism bias and gender of investors. Investment in low risk instruments does not differ for demographic variables of investors as all investors invest equally in safe investment mode. MBTI personality type is not highly significant variable for determining investment pattern of Indian inves- 
tors, but it definitely affects risk taking behaviour which in turn affects selection of investment instruments.

This study can be elaborated on a larger sample size and in different geographical locations. More investment biases like framing, herding, over confidence, mental accounting, etc can also be studied on investors. Risk return relationship can also be established with respect to personalities of investors.

Such studies are beneficial for financial investment advisiors while designing products, plans and investment programmes for their clients. This will help them understand how to deal with clients with different risk taking abilities and will ultimately increase satisfaction of clients with respect to the services and returns from their broking house or investment advisor.

\section{Conflicts of Interest}

The author declares no conflicts of interest regarding the publication of this paper.

\section{References}

[1] Sharpe, W.F. (1963) A Simplified Model for Portfolio Analysis. Management Science, 9, 277-293. https://doi.org/10.1287/mnsc.9.2.277

[2] Markowitz, H. (1952) Portfolio Selection. The Journal of Finance, 7, 77-91.

[3] Fama, E.F. (1970) Efficient Capital Markets: A Review of Theory and Empirical Work. The Journal of Finance, 25, 383-417. https://doi.org/10.2307/2325486

[4] Kahnemann, D. and Tversky, A. (1979) Prospect Theory: An Analysis of Decision under Risk. Econometrica, 47, 263-292. https://doi.org/10.2307/1914185

[5] Thaler, R. (1985) Mental Accounting and Consumer Choice. Marketing Science, 4, 199-214. https://doi.org/10.1287/mksc.4.3.199

[6] Barnea, A., Cronqvist, H. and Siegel, S. (2010) Nature or Nurture: What Determines Investor Behavior? Journal of Financial Economics, 98, 583-604.

https://doi.org/10.1016/j.jfineco.2010.08.001

[7] Baker, M. and Wurgler, J. (2007) Investor Sentiment in the Stock Market. Journal of Economic Perspectives, 21, 129-151. https://doi.org/10.1257/jep.21.2.129

[8] Kumar, A. and Lee, C.M.C. (2006) Retail Investor Sentiment and Return Comovements. Journal of Finance, 61, 2451-2486.

https://doi.org/10.1111/j.1540-6261.2006.01063.x

[9] MurithiSuriya, S., Narayanan, B. and Arivazhagan, M. (2012) Investors Behaviour in Various Investment Avenues-A Study. International Journal of Marketing and Technology, 2, 36-45.

[10] Chakraborty, S. and Digal, S.K. (2011) A Study of Saving and Investment Behaviour of Individual Households-An Empirical Evidence from Orissa. Personal Finance \& Investments. http://ssrn.com/abstract $=2168305$ https://doi.org/10.2139/ssrn.2168305

[11] Lascu, D.N., Babb, H.W. and Phillips, R.W. (1997) Gender and Investment: The Influence of Gender on Investment Preferences and Practices. Managerial Finance, 23, 179-191. https://doi.org/10.1108/eb018652

[12] Loible, C. and Hira, T.K. (2007) New Insights into Advising Female Clients on Investment Decisions. Journal of Financial Planning, 20, 68-75. 
[13] Barber, B.M. and Odean, T. (2001) Boys Will Be Boys: Gender, Overconfidence, and Common Stock Investment. Quarterly Journal of Economics, 116, 261-292. https://doi.org/10.1162/003355301556400

[14] Palsson, A.M. (1996) Does the Degree of Relative Risk Aversion Vary with Household Characteristics? Journal of Economic Psychology, 17, 771-787. https://doi.org/10.1016/S0167-4870(96)00039-6

[15] McLachan, J. and Gardner, J. (2004) A Comparison of Socially Responsible and Conventional Investors. Journal of Business Ethics, 52, 11-25. https://doi.org/10.1023/B:BUSI.0000033104.28219.92

[16] Getzner, M. and Grabner-Krauter, S. (2004) Consumer Preferences and Marketing Strategies for "Green Shares". Specifics of the Austrian Market. International Journal of Bank Marketing, 22, 260-279. https://doi.org/10.1108/02652320410542545

[17] Diamantopoulos, A.B., Schlegelmilch, B., Sinkovics, R.R. and Bohlen, G. (2003) Can Sociodemographics Still Play a Role in Profiling Green Consumers? A Review of the Evidence and an Empirical Investigation. Journal of Business Research, 56, 465-480. https://doi.org/10.1016/S0148-2963(01)00241-7

[18] Hong, H., Kubik, J.D. and Stein, J.C. (2004) Social Interaction and Stock Market Participation. Journal of Finance, 59, 137-163. https://doi.org/10.1111/j.1540-6261.2004.00629.x

[19] Love, D.A. (2010) The Effect of Marital Status and Children on Savings and Portfolio Choice. Review of Financial Studies, 23, 385-432.

https://doi.org/10.1093/rfs/hhp020

[20] Grinblatt, K. and Linnainmaa (2009) IQ and Stock Market Participation. Chicago Booth Research Paper No. 09-27.

[21] Lynch, A.W. (2001) Portfolio Choice and Equity Characteristics: Characterizing the Hedging Demands Induced by Return Predictability. Journal of Financial Economics, 62, 67-130. https://doi.org/10.1016/S0304-405X(01)00074-5

[22] Jurek, J.W. and Viceira, L.M. (2011) Optimal Value and Growth Tilts in Long-Horizon Portfolios. Review of Finance, 15, 29-74. https://doi.org/10.1093/rof/rfq013

[23] Larsen, L.S. and Munk, C. (2012) The Costs of Suboptimal Dynamic Asset Allocation: General Results and Applications to Interest Rate Risk, Stock Volatility Risk, and Growth/Value Tilts. Journal of Economic Dynamics and Control, 36, 266-293. https://doi.org/10.1016/j.jedc.2011.09.009

[24] Croson, R. and Gneezy, U. (2009) Gender Differences in Preferences. Journal of Economic Literature, 47, 448-474. https://doi.org/10.1257/jel.47.2.448

[25] Malmendier, U. and Nagel, S. (2011) Depression Babies: Do Macroeconomic Experiences Affect Risk-Taking? Quarterly Journal of Economics, 126, 373-416. https://doi.org/10.1093/qje/qjq004

[26] Graham, J.R. (1999) Herding among Investment Newsletters: Theory and Evidence. Journal of Finance, 54, 237-268. https://doi.org/10.1111/0022-1082.00103

[27] Morin, R.A. and Suarez, A.F. (1983) Risk Aversion Revisited. The Journal of Finance, 38, 1201-1216. https://doi.org/10.1111/j.1540-6261.1983.tb02291.x

[28] Holmstrom, B. and Milgrom, P. (1987) Aggregation and Linearity in the Provision of Intertemporal Incentives. Econometrica, 55, 303-328. https://doi.org/10.2307/1913238

[29] Kanodia, C., Bushman, R. and Dickhaut, J. (1989) Escalation Errors and the Sunk Cost Effect: An Explanation Based on Reputation and Information Asymmetries. 
Journal of Accounting Research, 27, 59-77. https://doi.org/10.2307/2491207

[30] Bernheim, B.D. (1994) A Theory of Conformity. Journal of Political Economy, 102, 841-877. https://doi.org/10.1086/261957

[31] Vroom, V. and Pahl, B. (1971) Relationship between Age and Risk Taking among Managers. Journal of Applied Psychology, 55, 399-405. https://doi.org/10.1037/h0031776

[32] Kahneman, D., Slovic, P. and Tversky, A. (1982) Judgment under Uncertainty: Heuristics and Biases. Cambridge University Press, Cambridge. https://doi.org/10.1017/CBO9780511809477

[33] Avery and Chevalier (1999) Herding over the Career. Economics Letters, 63, 327-333. https://doi.org/10.1016/S0165-1765(99)00039-7

[34] Li, X. (2002) Performance, Herding, and Career Concerns of Individual Financial Analysts. Working Paper, Vanderbilt University, Nashville.

[35] Boyson, N.M. (2003) Why Do Experienced Hedge Fund Managers Have Lower Returns. Working Paper, Purdue University, West Lafayette.

[36] Chevalier, J. and Ellison, G. (1999) Career Concerns of Mutual Fund Managers. Quarterly Journal of Economics, 114, 389-432. https://doi.org/10.1162/003355399556034

[37] Hong, H., Kubik, J.D. and Solomon, A. (2000) Security Analysts' Career Concerns and Herding of Earnings Forecasts. RAND Journal of Economics, 31, 121-144. https://doi.org/10.2307/2601032

[38] Lamont, O. (2002) Macroeconomic Forecasts and Microeconomic Forecasters. Journal of Economic Behavior and Organization, 48, 265-280. https://doi.org/10.1016/S0167-2681(01)00219-0

[39] Chevalier, J. and Ellison, G. (1999) Are Some Mutual Fund Managers Better than Others. Journal of Finance, 54, 875-899. https://doi.org/10.1111/0022-1082.00130

[40] Liang, B. (1999) On the Performance of Hedge Funds. Financial Analysts Journal, 55, 72-85. https://doi.org/10.2469/faj.v55.n4.2287

[41] Edwards, F.R. and Caglayan, M. (2001) Hedge Fund Performance and Manager Skill. Journal of Futures Markets, 21, 1003-1028. https://doi.org/10.1002/fut.2102

[42] Brachinger, H.W., Schubert, R., Brown, M. and Gysler, M. (1999) Financial Decision Making: Are Women Really More Risk Averse? American Economic Review, 89, 381-385. https://doi.org/10.1257/aer.89.2.381

[43] Schmidt, U. and Traub, S. (2002) An Experimental Test of Loss Aversion. Journal of Risk and Uncertainty, 25, 233-249. https://doi.org/10.1023/A:1020923921649

[44] Dreber, A., Apicella, C.L., Eisenberg, D.A., Garcia, J.R., Zamore, R.S., Lum, J.K. and Campbell, B. (2009) The 7R Polymorphism in the Dopamine Receptor D4 Gene (DRD4) Is Associated with Financial Risk-Taking in Men. Evolution and Human Behavior, 30, 85-92. https://doi.org/10.1016/j.evolhumbehav.2008.11.001

[45] Dreber, A., von Essen, E. and Ranehill, E. (2009) Outrunning the Gender Gap: Boys and Girls Compete Equally. Stockholm School of Economics Working Paper.

[46] Charness, G. and Gneezy, U. (2010) Portfolio Choice and Risk Attitudes: An Experiment. Economic Inquiry, 48, 133-146.

https://doi.org/10.1111/j.1465-7295.2009.00219.x

[47] Byrnes, J.P., Miller, W.D. and Schafer, W. (1999) Gender Differences in Risk Taking: A Meta-Analysis. Psychological Bulletin, 125, 367-383.

https://doi.org/10.1037/0033-2909.125.3.367 
[48] Olsen, R.A. (2014) Financial Risk Perceptions: A Consciousness Perspective. Qualitative Research in Financial Markets, 6, 66-74. https://doi.org/10.1108/QRFM-07-2012-0023

[49] Hartog, J. and Ferrer-i-Carbonell, A. and Jonker, N. (2000) On a Simple Survey Measure of Individual Risk Aversion. CESifo Working Paper Series No. 363. http://ssrn.com/abstract $=260938$

[50] Merikas, A. and Prasad, D. (2003) Factors Influencing Greek Investor Behaviour on the Athens Stock Exchange. Annual Meeting of the Academy of Financial Services, Denver.

[51] Kim, K.A. and Nofsinger, J.R. (2007) The Behaviour of Japanese Individual Investors during Bull and Bear Markets. The Journal of Behavioral Finance, 8, 138-153. https://doi.org/10.1080/15427560701545598

[52] Meziane, L., Sharon, X.L. and Gulnur, M. (2012) Optimism in Foreign Investors. Review of Behavioral Finance, 4, 8-27. https://doi.org/10.1108/19405971211261083

[53] Lim, S.S. (2006) Do Investors Integrate Losses and Segregate Gains? Mental Accounting and Investors Trading Decisions. Journal of Business, 79, 2539-2573. https://doi.org/10.1086/505243

[54] Brown, G.W. and Cliff, M.T. (2004) Investors Sentiment and the Near-Term Stock Market. Journal of Empirical Finance, 11, 1-27. https://doi.org/10.1016/j.jempfin.2002.12.001

[55] Fischer, R. and Gerhardt, R. (2007) Investment Mistakes of Individual Investors and the Impact of Financial Advice. Working Paper, European Business School, London.

[56] Odean, T. (1998) Are Investors Reluctant to Realize Their Losses? The Journal of Finance, 53, 1775-1798. https://doi.org/10.1111/0022-1082.00072

[57] Gakhar, D.V. and Prakash, D. (2013) A Study of the Relationship between Overconfidence Bias and Myers-Briggs Type Indicator. Mind and Management, Bloomsbery Publications, 65-77.

[58] Locke, P.R. and Mann, S.C. (2001) House Money and Overconfidence on the Trading Floor. Working Paper, George Washington University, Washington DC.

[59] Heath, C. and Tversky, A. (1991) Preference and Belief: Ambiguity and Competence in Choice under Uncertainty. Journal of Risk and Uncertainty, 4, 5-28. https://doi.org/10.1007/BF00057884

[60] Frascara, J. (1999) Cognition, Emotion and Other Inescapable Dimensions of Human Experience. Visible Language, 33, 74-87.

[61] Glaser, M., Langer, T. and Weber, M. (2004) Overconfidence of Professionals and Lay Men: Individual Differences within and between Tasks. Working Paper, University of Mannheim, Mannheim.

[62] Filbeck, G., Hatfield, P. and Horvath, P. (2005) Risk Aversion and Personality Type. The Journal of Behavioral Finance, 6, 170-180. https://doi.org/10.1207/s15427579jpfm0604_1

[63] Durand, R.B., Newby, R., Peggs, L. and Siekierka, M. (2013) Personality. Journal of Behavioral Finance, 14, 116-133. https://doi.org/10.1080/15427560.2013.791294

[64] Durand, R., Newby, R., Tant, K. and Trepongkaruna, S. (2013) Overconfidence, Overreaction and Personality. Review of Behavioral Finance, 5, 104-133.

https://doi.org/10.1108/RBF-07-2012-0011

[65] Costa, P.T. and McRae, R.R. (1992) Revised NEO Personality Inventory Manual. Psychological Assessment Resources Inc., Odessa. 
[66] Bem, S.L. (1994) Short-Form Bem Sex-Role Inventory (BSRI). Consulting Psychologists Press, Palo Alto.

[67] Jackson, D.N. (1976) Personality Inventory Manual. Research Psychologists Press, Goshen.

[68] Shollapur, M.R. and Kuchanur, A.B. (2008) Identifying Perceptions and Perceptual Gaps: A Study on Individual Investors in Selected Investment Avenues. The ICFAI University Journal of Behavioral Finance, 5, 48-64.

[69] Sellappan, R. (2013) Investment Attitude of Women towards Different Sources of Securities-A Factor Analysis Approach. Global Research Analysis, 13, 34-36.

[70] Pati, P. and Shome, D. (2011) Do Households Still Prefer Bank Deposits? An Analysis of Shift in Savings and Savings Determinants. IUP Journal of Bank Management, 10, 46-59.

[71] Mohanta, G. and Debasish, S. (2011) A Study on Investment Preference. Journal of Management Thought and Practice, 3, 1-10.

[72] Chaturvedi, M. and Khare, S. (2012) Study of Saving Pattern and Investment Preferences of Individual Household in India. International Journal of Research in Commerce \& Management, 3, 115-120.

[73] http://www.bmo.com/newsletter/insurance/pdf/Investor_Profile_Questionnaire-35 8E.pdf

[74] Pompian, M.M. (2006) Behavioural Finance and Wealth Management-How to Build Optimal Portfolios That Account for Investor Biases. John Wiley and Sons, Hoboken.

[75] Balasuriya, J., Muradoglu, Y.G. and Ayton, P. (2010) Optimism and Portfolio Choice. http://ssrn.com/abstract $=1568908$

https://doi.org/10.2139/ssrn.1568908 